\title{
Peningkatan Locus of Control dalam Mereduksi Prokrastinasi Akademik Mahasiswa
}

\author{
Firman Antoni ${ }^{1}$, Taufik ${ }^{2}$, Frischa Meivilona Yendi ${ }^{3}$, Verlanda Yuca ${ }^{4}$ \\ ${ }^{1234}$ Universitas Negeri Padang \\ *) Correspondence e-mail: firmanantoni1998@gmail.com
}

\begin{abstract}
Prokrastinasi akademik masih terjadi di dunia pendidikan, termasuk mahasiswa. Mahasiswa cenderung senang menunda-nunda dalam mengerjakan tugas kuliah dan lebih senang beraktivitas lainnya. Salah satu faktor dari prokrastinasi akademik adalah locus of control. Locus of control yang rendah menyebabkan mahasiswa melakukan penundaan dalam mengerjakan tugas sehingga kalaupun selesai tugas tidak optimal karena dikerjakan pada waktu deadline. Locus of control dapat ditingkatkan dengan memvisualisasikan kemajuan, mengoptimalkan potensi, tentukan deadline tugas, beraktivitas sebelum feeling in the mood, hindari rasionalisasi berlebihan, lawan hambatan, fleksibel terhadap tujuan, kurangi perfeksionis, dan berikan reward pada sesuatu yang dicapai. Hal demikian tidak akan lepas dari dosen, orang tua dan mahasiswa itu sendiri.
\end{abstract}

Keywords: Locus of Control, Prokrastinasi Akademik.

Article History: Received on 12/05/2019; Revised on 12/06/2019; Accepted on 07/07/2019; Published Online: $14 / 07 / 2019$.

(c) (1) This is an open access article distributed under the Creative Commons Attribution License, which permits unrestricted use,

\section{Pendahuluan}

Belajar merupakan hal yang penting bagi setiap manusia dan merupakan proses yang tidak ada henti-hentinya. Melalui belajar, tingkah laku manusia akan terbentuk dengan baik karna belajar dapat dikatakan sebagai sebuah perubahan tingkah laku dari perilaku sebelumnya menuju peilaku setelah melalui proses belajar. Tujuan utama dari belajar adalah memperoleh suatu pemahaman akan hal-hal yang dipelajari sehingga bermanfaat untuk kehidupan sehari-hari. Dapat disimpulkan bahwa belajar merupakan segenap rangkaian usaha melalui tingkah laku yang dilakukan secara sadar oleh seseorang dan mengakibatkan perubahan dalam dirinya berupa penambahan pengetahuan, kemahiran berdasarkan pengalamannya dalam pengembangan ketiga ranah kecakapan yakni kognitif, afektif dan psikomotor.

Akinsola \& Tella (Sofyan, 2014) menjelaskan bahwa "The target oriented student objectives are to get good grades and commit to reach that goal and exercise behaviors such as focusing on difficult tasks, completed all assignments, manage time carefully, and get help when needed". Maka dapat disimpulkan bahwa muara utama yang harus dilakukan oleh siswa dalam belajar adalah mendapatkan nilai yang tinggi dan mempunyai komitmen. untuk menjadi tujuan dan perilaku seperti: fokus dengan kesulitan tugas, melengkapi semua tugas, mengatur waktu dengan hati-hati, dan mencari bantuan jika membutuhkan. 
Sebagai seorang mahasiswa belajar adalah tugas yang sangat berarti. Pelaksanaan perkuliahan mahasiswa tidak terlepas dari Tri Darma Perguruan Tinggi, yaitu mendapatkan pendidikan, melakukan penelitian, dan pengabdian kepada masyarakat. Keberhasilan mahasiswa dalam belajar dapat tercapai apabila mahasiswa mengerahkan kemampuan dan memanfaatkan segala kesempatan yang dimiliki. Untuk itu mahasiswa perlu mengembangkan kemampuan dan kesempatan tersebut. Namun kenyataan sebenarnya hal demikian masih belum terjadi. Di kalangan mahasiswa masih ada yang belum mampu memanfaatkan waktu dalam belajar, mengerjakan tugas perkuliahan sehingga cenderung melakukan penundaan.

Sejalan dengan itu, penelitian yang dilakukan Sofyan (2014) memperlihatkan mahasiswa yang melakukan penundaan untuk memulai atau menyelesaikan tugas $(62,5 \%)$, mahasiswa yang mengalami keterlambatan dalam mengerjakan tugas $(40 \%)$, mahasiswa yang mengalami kesenjangan waktu antara rencana dan kinerja aktual (55\%), serta mahasiswa yang melakukan aktifitas lain yang lebih menyenangkan dibanding menyelesaikan tugas (62,5\%). Jika perilaku di atas dibiarkan begitu saja, maka tidak menutup kemungkinan mahasiswa menghabiskan masa studinya lebih dari empat tahun.

Beberapa penelitian yang berkaitan dengan prokrastinasi akademik memperlihatkan penundaan banyak dilakukan oleh siswa dan mahasiswa. Penelitian yang dilakukan oleh Juliawati (2014) di salah satu sekolah di kota Padang memperlihatkan kecenderungan prokrastinasi akademik siswa berada pada kategori tinggi $(60 \%)$, kemudian kategori sedang (20\%), dan kategori rendah (20\%). Burka \& Yuen (Sofyan, 2014) menemukan sejak tahun 2007 prokrastinasi yang dilakukan meningkat sebanyak $75 \%$, di mana $50 \%$ siswa sering melakukan prokrastinasi dan $25 \%$ prokrastinasi dilakukan oleh orang dewasa.

Perilaku prokrastinasi akademik yang berkelanjutan akan menumbuhkan ketidakdisiplinan dalam diri mahasiswa, kualitas sumber daya manusia yang dihasilkan juga akan semakin rendah. Penelitian yang dilakukan Veronica (2012) pada mahasiswa program studi pendidikan sejarah UNP, terlihat prokrastinasi akademik pada kategori tinggi (56,36\%), pada kategori sedang (40\%), dan pada kategori rendah $(3,64 \%)$. Selain itu penelitian yang dilakukan Tetan (2013) menemukan prokrastinasi akademik mahasiswa cenderung tinggi hingga sangat tinggi (56\%) dan (44\%) cenderung rendah hingga sangat rendah. Berdasarkan hasil penelitian tersebut dapat disimpulkan prokrastinasi akademik terjadi pada siswa dan mahasiswa.

Dengan demikian prokrastinasi akademik di kalangan peserta didik terutama mahasiswa memiliki kuantitas yang cukup besar. Sebagai mahasiswa dalam usia muda, mereka tidak luput dari permasalahan yang berkaitan dengan masalah belajar. Pada umumnya di usia ini mereka menyukai kegiatan yang dianggap lebih menyenangkan seperti menonton film, mendengarkan musik, jalan-jalan dengan teman, chatting di media sosial maupun sekedar melihat-lihat, atau bermain games dari pada menyelesaikan tugas dan belajar. Selain itu mereka juga kerap merasa tidak nyaman dengan kondisi perkuliahan, lingkungan teman sebaya, cara dosen mengajar dan tugas yang diberikan terlalu banyak. Keadaan demikian menyebabkan mahasiswa melakukan penundaan dalam belajar maupun mengerjakan tugas-tugas perkuliahan karna beranggapan mudah dalam menyelesaikan dan mempunyai waktu panjang untuk menyelesaikan tugas-tugas 
tersebut sehingga cenderung akan mengalami masalah dengan waktu tugas yang sudah deadline sehingga hasil yang diperoleh tidak optimal. Keadaan demikian disebut sebagai prokrastinasi akademik.

Prokrastinasi akademik dipengaruhi oleh berbagai faktor, salah satu diantarnya adalah locus of control. Rotter (Loice, 2014: 02) menjelaskan bahwa "Locus of control as the extent to which people perceived that them or external factors such as chance and powerful others are in control of the events that influence their lives". Locus of control pada individu dilihat dari sejauh mana individu merasa sebagai diri sendiri atau karena bantuan dan tergantung pada orang lain. Hal demikian sejalan dengan apa yang terjadi saat ini dikehidupan mahasiswa. Penelitian yang dilakukan Desy, Marjohan \& Yeni (2019) menjelaskan masih banyaknya peserta didik yang bergantung dengan keadaan dari luar, misalnya: dalam mengerjakan tugas secara deadline, meng-copy-paste tugas senior, merasa tidak mampu mengerjakan tugas, tidak mampu mengatur waktu belajar dengan baik dan kurangnya inisiatif dalam menyelesaikan tugas yang dimiliki sehingga cenderung melakukan prokrastinasi akademik.

Berikutnya penelitian yang dilakukan oleh Yosefhin, Widya \& Agus (2016: 91) menjelaskan bahwa salah satu faktor yang menjadi penyebab prokrastinasi akademik pada mahasiswa adalah perasaan takut akan gagal (fear of failure), yang merupakan dorongan menghindari kegagalan terutama konsekuensi negatif berupa masa lalu. Mahasiswa mudah takut akan kegagalan, misalnya dalam menyelesaikan tugas akademik dan saat menghadapi ujian. Selain itu tingkat locus of control juga sangat mempengaruhi. Apabila individu memiliki internal locus of control maka ia meyakini sesuatu yang terjadi tergantung apa yang sudah dirinya lakukan sendiri. Berbeda dengan yang memiliki external locus of control, mereka meyakini segala sesuatu sudah ditentukan maka akan bergantung dengan apa yang orang lain lakukan.

\section{Prokrastinasi Akademik}

Menurut Rumiani (Ridwan, 2013) menjelaskan bahwa kecenderungan melakukan penundaan dalam melaksanakan suatu aktivitas atau pekerjaan secara berulang-ulang disebut sebagai prokrastinasi. Selanjutnya dalam pendidikan kecenderungan menunda menyelesaikan tugas yang dilakukan oleh seorang peserta didik disebut sebagai prokrastinasi akademik. Senada dengan itu, Senecal, Koestner \& Vallerand (Gohil, 2014) mendefinisikan "Academik procrastination can be undestood as knowing that one is supposed to, and perhaps even wanting to, complete an academic task but failing to perform the activity whitin the expected or desired time frame". Maksudnya adalah prokrastinasi akademik merupakan penundaan tugas akademik yang diulang-ulang kemudian gagal dalam menyelesaikan tepat pada waktunya atau sudah diselesaikan namun hasilnya tidak maksimal karena sudah deadline, menimbulkan kecemasan dalam penyelesaiannya, sehingga jumlah kesalahan yang dilakukan cenderung tinggi.

Menurut Ghufron \& Risnawita (2010: 121) prokrastinasi akademik adalah jenis penundaan yang dilakukan mahasiswa pada jenis tugas formal yang berhubungan dengan tugas akademik. Prokrastinasi akademik yang dilakukan secara terus-menerus oleh mahasiswa akan menghambat pencapaian prestasi akademik. Tugas yang dikerjakan oleh mahasiswa hasilnya tidak akan optimal, karena dikerjakan dalam kondisi yang 
mendesak. Selain itu, mahasiswa menjadi tidak disiplin dan memiliki daya saing yang rendah. Sejalan dengan itu Balkis \& Duru (2009:19) menyatakan "Procrastination is defined as a behavior in which an individual leaves a feasible, important deed planned beforehand to another time without any sensible reason". Artinya prokrastinasi merupakan perilaku individu yang meninggalkan kegiatan penting yang bisa dilakukan dan telah direncanakan sebelumnya tanpa alasan yang masuk akal.

\section{Ciri-ciri Prokrastinasi Akademik}

Miligram memberikan gambaran prokrastinasi ke dalam empat perilaku spesifik yang meliputi: (1) suatu perilaku yang melibatkan unsur penundaan, baik untuk memulai maupun menyelesaikan suatu tugas atau aktivitas; (2) menghasilkan akibat-akibat lain yang lebih jauh misalnya keterlambatan menyelesaikan tugas maupun kegagalan dalam mengerjakan tugas; (3) melibatkan suatu tugas yang dipersepsikan oleh prokrastinator (pelaku prokrastinasi) sebagai suatu tugas yang penting, seperti misalnya tugas sekolah; dan (4) menghasilkan keadaan emosional yang tidak menyenangkan seperti perasaan cemas, bersalah, marah dan panik (Ghufron, 2010).

Seorang prokrastinator menghabiskan waktu yang dimilikinya untuk mempersiapkan diri secara berlebihan. Selain itu, juga melakukan hal-hal yang tidak dibutuhkan dalam penyelesaian suatu tugas, tanpa memperhitungkan keterbatasan waktu yang dimilikinya. Kadang-kadang tindakan tersebut mengakibatkan seseorang tidak berhasi menyelesaikan tugasnya secara memadai. Kelambanan, dalam arti lambannya kerja seseorang dalam melakukan suatu tugas dapat menjadi ciri utama prokrastinator akademik.

Ferrari (Tetan, 2013) menyatakan bahwa terdapat tiga jenis prokrastinator, diantaranya yaitu: (1) Arousal Procrastinators: disebut juga Thrill-seeker atau pencarisensasi. Jenis penunda ini mengerjakan atau menangani tugasnya pada menit-menit terakhir sehingga terburu-buru dalam menyelesaikannya; (2) Avoidance Procrastinators: jenis penunda ini selalu menghindaritugas atau merasa bahwa tugas tersebut membosankan. Hal tersebut dilakukan mungkin untuk menghindari perasaan takut gagal (fear of failure) atau bahkan takut sukses (fear of success). Mereka lebih suka jika orang lain berpikir bahwa mereka kurang usaha dibandingkan kurang mampu. Selain itu, mereka juga ingin menghindari sesuatu yang mereka anggap tidak menyenangkan; (3) Decisional Procrastinators : jenis penunda ini selalu ragu dalammengambil keputusan. Mereka tidak dapat membuat keputusan atau memberikan kesimpulan dengan tepat waktu. Dengan tidak membuat keputusan, mereka merasa terbebas dari tanggung jawab.

\section{Jenis-jenis Tugas Pada Prokrastinasi Akademik}

Mahasiswa merupakan bagian dari sivitas akademika tidak terlepas dari perilaku prokrastinasi. Menurut Solomon \& Rothblum (Gufron \& Rsnawita, 2010) terdapat enam area akademik yang sering diprokrastinasi oleh mahasiswa sebagai berikut.

1) Tugas mengarang, meliputi penundaan melaksanakan kewajiban atau tugas-tugas menulis, misalnya menulis makalah, laporan, atau tugas mengarang lainnya.

2) Tugas belajar menghadapi ujian, mencakup penundaaan belajar untuk mengadapi ujian, misalnya ujian tengah semester, akhir semester, atau ulangan mingguan.

3) Tugas membaca, meliputi adanya penundaan untuk membaca buku atau referensi yang berkaitan dengan tugas akademik yang diwajibkan.

4) Kerja tugas administratif, seperti menyalin catatan, mendaftarkan diri dala presensi kehadiran, daftar peserta pratikum, dan sebagainya. 
5) Menghadiri pertemuan, yaitu penundaan maupun keterlambatan dalam menghadiri pelajaran, pratikum, dan pertemuan-pertemuan lainnya.

6) Penundaan dalam kinerja akademik secara keseluruhan, yaitu menunda mengerjakan atau menyelesaikan tugas-tugas akademik secara keseluruhan.

\section{Teori Perkembangan Prokrastinasi Akademik}

Setiap teori memiliki sudut pandang yang berbeda-beda mengenai perkembangan prokrastinasi akademik. Ghufron \& Risnawita (2010) mengemukakan tiga teori yang menjelaskan prokrastinasi akademik sebagai berikut.

1) Psikodinamik, teori ini lebih menekankan bahwa pengalaman masa kanak-kanak individu akan mempengaruhi proses perkembangan koognitif ketika dewasa, terutama trauma. Individu yang pernah mengalami trauma akan tugas tertentu, misalnya gagal dalam menyelesaikan tugas perkuliahannya, akan cenderung melakukan prokrastinasi ketika dihadapkan pada tugas yang sejenis. Perilaku penundaan atau prokrastinasi merupakan akibat dari penghindaran tugas dan sebagai bentuk mekanisme pertahanan diri.

2) Behavioristik, teori ini beranggapan prokrastinasi yang dilakukan individu merupakan hasil pembelajaran. Individu yang melakukan prokrastinasi akademik karena dia mendapatkan punishment atas perilakunya. Individu yang pernah merasakan sukses karena melakukan penundaan dalam membuat tugas, akan cenderung melakukan perbuatan yang sama yaitu menunda. Selain itu, prokrastinasi akademik muncul karena adanya reward yang lebih menyenangkan dari objek prokrastinasi. Individu yang merasakan bermain video game lebih menyenangkan daripada menyelesaikan tugas akademik, mengakibatkan tertundanya penyelesaian tugas akademik karena waktunya habis bermain video game.

3) Kognitif dan behavioral-kognitif, teori ini menjelaskan prokrastinasi akademik terjadi karena adanya keyakinan irasional yang dimiliki individu. Keyakinan irasional muncul disebabkan oleh kesalahan individu dalam mempersepsikan tugas sekolah. Individu memandang tugas sekolah sebagai suatu yang tidak menyenangkan. Dengan pemikiran irasional tersebut, individu lebih memilih menunda untuk menyelesaikan tugas sekolahnya atau menyelesaikan tugas terburuburu yang mengakibatkan tugasnya tidak optimal.

\section{Locus of Control}

Salah satu penyebab dari munculnya prokrastinasi akademik adalah locus of control. Selanjutnya Engko dan Gudono (Ridwan, 2013: 73) bahwa locus of control merupakan cara pandang seseoang untuk bisa menyelesaikan permasalahan yang terjadi pada dirinya. Kemudian didukung oleh pendapat sebelumnya dalam penelitian Danta dan Rahmat (Ghufron \& Risnawita (2010)) bahwa locus of control adalah cara seseorang mengontrol dirinya dan memberikan tanggung jawab terhadap peristiwa yang terjadi pada dirinya. Locus of control sendiri terbagi dalam dua bagian, yaitu interal dan eksternal. Walker (Ridwan, 2013: 73) menjelaskan bahwa internal locus of control memiliki hubungan positif terhadap prestasi akademik siswa. Hal ini mengindikasikan bahwa locus of control internal merupakan keyakinan yang muncul dalam diri individu itu sendiri dan memandang dirinya mampu melakukan sesuatu berdasarkan kemampuan dirinya. Larsen dan David (Ghufron \& Risnawita (2010)) menjelaskan bahwa orang yang memiliki 
locus of control eksternal yang tinggi meyakini bahwa hasil belajar yang diperoleh tergantung pada orang lain dan keberuntungan semata.

Penelitian yang dilakukan oleh Nugrasanti (Yosefhin, Widya, \& Agus, 2016) tentang locus of control dan prokrastinasi akademik mahasiswa, menjelaskan bahwa terhadap hubungan yang signifikan antara locos of control dengan prokrastinasi akademik, dimana semakin external locus of control yang dimiliki seorang mahasiswa maka semakin tinggi tingkat prokrastinasi akademik. Sebaliknya, semakin internal locus of control mahasiswa maka semakin rendah tingkat prokrastinasi akademik yang dilakukan.

Sejalan dengan itu, penelitian yang dilakukan oleh Yosefhin, Widya \& Agus (2016: 102) tentang locus of control dan prokrastinasi pada mahasiswa pendidikan ekonomiangkatan 2013 fakultas ekonomi universitas negeri jakarta, menjelaskan bahwa terdapat pengaruh yang negatif antara locus of control dengan prokrastinasi. Semakin tinggi (internal) locus of control maka akan semakin rendah tingkat prokrastinasi pada mahasiswa. Sebaliknya, semakin rendah (eksternal) locus of control maka akan semakin tinggi tingkat prokrastinasi yang dilakukan mahasiswa tersebut.

\section{Faktor-faktor yang Mempengaruhi Locus of Control}

Terdapat beberapa faktor yang dapat mempengaruhi locus of control dalam diri individu, diantaranya sebagi berikut: (1) Perbedaan umur dan jenis kelamin dimana bahwa pria dinilai memiliki locus of control yang lebih tinggi dibandingkan dengan wanita, (2) Faktor sosial, emakin rendah tingkat sosial individu maka semakin eksternal locus of control yang dimiliki oleh individu. (3) Faktor keluarga, keluarga merupakan temapt berinteraksi pertama bagi anak. Jika tingkah laku anak mendapatkan respon dari orang tuanya maka secara tidak langsung anak memperoleh kehangatan dan perhatian maupun perlindungan, hal demikian membawa anak untuk memiliki locus of control internal.

\section{Eksternal Locus of Control Pada Mahasiswa}

Mahasiswa yang melakukan tindakan prokrastinasi umumnya tidak dapat mengelola waktu belajarnya dengan baik. Mereka tidak memulai ataupun menyelesaikan tugasnya dengan segera dan beranggapan bahwa masih memiliki cukup waktu untuk menyelesaikan tugas-tugas tersebut. Sehingga tugas yang harus diselesaikan semakin menumpuk dan mereka kesulitan untuk memilih tugas yang hendak diselesaikan terlebih dahulu. Pada akhirnya, mereka akan mengerjakannya dalam tengat waktu (deadline), sehingga hasil yang didapatkan tidak optimal.

Selain itu, kondisi fisik ataupun mental yang lelah juga menjadi penyebab siswa melakukan tindakan prokrastinasi. Kelelahan (fatigue) merupakan keadaan dimana tubuh dan jiwa terasa letih bukan hanya sekedar capek, tetapi lesu dan tidak bergairah, menggambarkan keadaan fisik dan/atau mental menjadi lelah dan lemah. Pada kondisi ini, kemampuan fisik ataupun mental mahasiswa menurun yang diikuti perasaan mengantuk dan tidak mampu berkonsentrasi dengan baik, sehingga berdampak pada tertundanya pengerjaan tugas-tugas. Kelelahan dan prokrastinasi akademik memiliki kaitan, karna demikian prokrastinasi yang dilakukan dapat menimbulkan kelelahan.

Ketika mahasiswa merasa lelah, mereka akan melakukan penundaan terhadap tugas-tugasnya dan memilih untuk menyelesaikannya dikemudian hari. Kondisi demikian mengakibatkan tugas-tugas tersebut semakin menumpuk dan mengubah persepsi terhadap tugas sederhana menjadi sulit untuk diselesaikan. Pada akhirnya mereka akan terus melakukan penundaan sebagai bentuk penghindaran terhadap tugas- 
tugas tersebut dan membuat mereka menjadi kewalahan dan kelelahan dalam menyelesaikannya.

Mahasiswa dengan motivasi untuk berhasil atau berprestasi yang rendah juga cenderung akan melakukan tindakan prokrastinasi terhadap kewajiban atau tugas-tugas perkuliahan. Motivasi berprestasi merupakan suatu dorongan dalam diri seseorang untuk mencapai tujuan agar sukses dan berhasil dalam suatu kompetisi yang diukur dengan beberapa ukuran keberhasilan, misalnya dengan membandingkan prestasi sebelumnya dengan prestasi saat ini atau membandingkan prestasi sendiri dengan orang lain. Mahasiswa dengan motivasi berprestasi yang rendah cenderung lebih suka melakukan kegiatan yang tidak ada kaitannya dengan keberhasilan studi mereka dan menyianyiakan waktunya untuk melakukan kegiatan yang dianggapnya lebih menyenangkan daripada memulai untuk belajar ataupun menyelesaikan tugas-tugasnya.

Pada umumnya, siswa yang memiliki eksternal locus of control, memiliki harga diri (self-esteem) yang rendah. menggambarkan sejauh mana individu tersebut menilai dirinya sebagai orang yang memiliki kemampuan dan keberartian. Harga diri (self-esteem) yang rendah akan menolak dirinya sebagai sesuatu yang berharga dan tidak Bertanggung jawab terhadap kehidupannya. Pentingnya pemenuhan harga diri individu, khususnya pada kalangan remaja, terkait erat dengan dampak negatif jika mereka tidak memiliki harga diri yang mantap. Mereka akan mengalami kesulitan dalam menampilkan perilaku sosialnya, merasa inferior dan canggung. Namun apabila kebutuhan harga diri mereka dapat terpenuhi secara memadai, kemungkinan mereka akan memperoleh kesuksesan, percaya diri (Self-confidence), bertanggungjawab dan merasa memiliki nilai dalam kehidupannya.

\section{Upaya dalam Meningkatkan Internal Locus of Control}

External locus of control yang dimiliki mahasiswa sangat merugikan dan menimbulkn prokrastinasi akademik. Prokrastinasi akademik yang dilakukan mahasiswa akan berdampak buruk pada prestasi akademik. Selain itu mahasiwa menjadi tidak disiplin, sehingga memiliki manajemen waktu yang buruk. Hal ini harus mendapat perhatian agar prokrastinator tidak akan mengalami permasalahan secara berulang-ulang karena mempunyai external locus of control.

Menurut Burka \& Yuen (Ridwan, 2013) ada beberapa hal yang dapat dilakukan dalam rangka meningkatkan internal locus of control untuk mereduksi prokrastinasi akademik diantaranya: (1) visualisasikan kemajuan, (2) optimalkan potensi sukses, (3) tetapkan batas waktu penuntasan kerja, (4) mulailah bekerja sebelum feeling in the mood, (5) hindari melakukan rasionalisasi, (6) hadapi dengan hambatan awal dalam bekerja, (7) jika diperlukan bersikap fleksibel terhadap tujuan, (8) kurangi kebutuhan akan kesempurnaan, dan (9) berikan penghargaan terhadap kemajuan yang telah dicapai.

Sejalan dengan itu, Solomon \& Rothblum (Ghufron, M. N., \& Risnawita, R. 2010) menjelaskan beberapa hal yang dapat dilakukan untuk membantu mengurangi prokrastinasi akademik sebagai berikut.

1) Mengakui prokrastinasi adalah masalah yang akan menghambat pencapaian prestasi akademik.

2) Mengingat mengenai nilai-nilai dan tujuan hidup. Berpikir mengenai bagaimana prokrastinasi dapat melemahkan tujuan-tujuan mereka. 
3) Mengelola waktu mereka secara efektif dan bijaksana. Manajemen waktu yang baik akan mempermudah dalam melaksanakan kegiatan sehari-hari selain tugas akademik. Salah satu caranya dengan membuat daftar harian yang harus dijalankan dengan baik.

4) Menggunakan strategi ilmu perilaku. Strategi ilmu perilaku dapat membangun penghargaan untuk diri mereka sendiri ketika mampu menyelesaikan tugas dengan optimal. Strategi ilmu perilaku dapat dilakukan dengan mengidentifikasi pengalih perhatian yang mungkin mencegah agar berfokus pada tugas da aktifitas yang paling penting.

5) Menggunakan strategi kognitif. Strategi kognitif diterapkan dengan cara membantu belajar untuk mampu mengalahkan perhatian pada hal-hal lain yang akan merugikannya.

Juga menjelaskan bahwa untuk meningkatkan internal locus of control pada mahasiswa terdapat tiga elemen yang berpengaruh, yaitu sebagai berikut:

1) Dosen, diharapkan memberikan edukasi mahasiswa mengenai locus of control agar mahasiswa dapat mengatur kegiatan belajarnya dengan baik dan terhindar dari tindakan prokrastinasi (penundaan) dalam menyelesaikan tugas-tugasnya.

2) Orang tua, harus rajin dalam mendukung penanaman external locus of control pada anak-anak mereka. Hal ini dapat dilakukan dengan memberi nasehat-nasehat yang membangun dan cara didik yang disiplin dan tegas, agar anak terpacu untuk mengatur belajarnya dengan baik dan lebih termotivasi dalam belajar, sehingga akan meminimalisir terjadinya prokrastinasi.

Mahasiswa, sebagai peserta didik cara paling baik adalah dengan menginternalkan locus of control yang ada pada diri sendiri. Mahasiswa yang memiliki locus of control yang rendah sebaiknya belajar untuk menyusun dan mengatur kegiatan belajarnya agar lebih terarah dan menyenangkan sehingga tujuan belajar dapat tercapai dengan baik. Mahasiswa harus merasionalkan pemikiran dan memprioritaskan semua aktivitas yang terpenting, dengan ini mahasiswa akan mampu menekan eksternal locus of control menjadi internal locus of control dalam rangka menurunkan tingkat prokrastinasi akademik.

\section{KESIMPULAN}

Berdasarkan pembahasan tersebut, maka dapat dikemukakan kesimpulkan sebagai berikut:

1) Prokrastinasi akademik masih banyak dialami oleh mahasiswa.

2) Prokrastinasi akademik dikarenakan tingginya external locus of control pada mahasiswa yang meyakini bahwa segala sesuatu yang terjadi tergantung pada orang lain dan merendahkan kemampuan dirinya sendiri.

3) Prokrastinasi akademik dapat diturunkan dengan cara meningkatkan locus of control. Dimana semakin internal locus of control yang dimiliki mahasiswa maka semakin rendah tingkat prokrastinasi akademiknya.

4) Peningkatan locus of control dapat dilakukan dengan mengarahkan individu agar memiliki internal locus of control. Beberapa diantaranya adalah dengan memberikan edukasi pada remaja akan pentingnya internal locus of control,pemahaman kepada mahasiswa dengan lingkungan sekitarnya bahwa yang menentukan keberhasilan adalah dirinya sendiri, menyusun prioritas kegiatan, visualisasi kemajuan, 
beraktivitas sebelum feeling in the mood, menggunakan strategi ilmu perilaku dan kognitif, pengelolaan waktu dengan efektif, dan bersifat fleksibel dalam menghadapi tujuan.

\section{REFERENCES}

Balkis, M., \& Duru, E. (2009). “Prevalence of Academic Procrastination Behavior Among Pre-Service Teachers, and its Relationship with Demographics and Individual Preferences". Journal of Theory and Practices in Education, 5 (1): 18-32.

Desy, M. L., Marjohan., \& Yeni, K. (2019). Kontribusi Locus of Control Dan Perfeksionis Terhadap Prokrastinasi Akademik Siswa Serta Implikasinya Dalam Pelayanan Bimbingan dan Konseling Di SMAN 10 Padang. Jurnal Sosial Humaniora, 2 (1), 42-53.

Ghufron, M. N., \& Risnawita, R. (2010). Teori-Teori Psikologi. Yogyakarta: Ar Ruzz Media Group.

Gohil, E. (2014). "Procrastination and Self Esteem A Gender Based Study". Lecturer, Departmen of Psychology University of Jammu, Jammu and Kashmir. Global Journal of Interdisciplinary Social Sciences, 3 (3): 91-95.

Juliawati, D. (2014). “Efektifitas Layanan Bimbingan Kelompok untuk Mengurangi Prokrastinasi Akademik Siswa". Tesis tidak diterbitkan. Padang: Program Studi S2 BK FIP UNP.

Loice, M. C. (2014). “The Influence of Locus of Control on Employees Perceptions of the Effectiveness of the Performance Appraisal at Kenya Revenue Authority (Southern Region)". A Reseach Project Summitted in Partial Fulfillment of the Requirements for the Award of the Degree of Master of Business Administration (MBA), (Online), (www.erepository.uonbi.ac.ke/.../Mutai The\%20influen, diakses 18 Desember 2019).

Ridwan. (2013). "Peranan Etika Kerja Islam Terhadap Hubungan Locus of Control dengan Kinerja Karyawan”. Jurnal Trikonomika. 12 (1).

Sofyan, Z. I. (2014). “Dampak Prokrastinasi Akademik terhadap Kepuasan Hidup pada Mahasiswa Teknik Elektro Industri UNP Angkatan 2010". Skripsi tidak diterbitkan. Padang: Program Studi Psikologi BK FIP UNP.

Tetan, M. J. (2013). “Hubungan Self Esteem dan Prokrastinasi Akademik pada Mahasiswa Angkatan 2010 Fakultas Psikologi Universitas Surabaya". Journal Ilmiah Mahasiswa Universitas Surabaya, 2 (1): 1-17.

Veronica, S. (2012). “Hubungan antara Self Control Dengan Prokrastinasi Akademik Pada Mahasiswa Program Studi Pendidikan Sejarah Universitas Negeri Padang". Skripsi tidak diterbitkan. Padang: Program Studi Psikologi BK FIP UNP.

Yosefhin, R. E., Widya, P., \& Agus, W. (2016). "Locus of Control Dan Prokrastinasi Pada Mahasiswa Pendidikan Ekonomi Angkatan 2013". Jurnal Pendidikan Ekonomi dan Bisnis, 4 (2): 87-106. 